\title{
Pengembangan Lembar Kerja Siswa Berbasis Masalah dengan Strategi Heuristic untuk Meningkatkan Kemampuan Literasi Matematis
}

\author{
Mega Nur Prabawati ${ }^{*}$, Tatang Herman ${ }^{2}$ dan Turmudi ${ }^{3}$ \\ Pendidikan Matematika, Universitas Siliwangi \\ Jalan Siliwangi No. 24 Tasikmalaya \\ 1*meganurprabawati@unsil.ac.id \\ Pendidikan Matematika, Universitas Pendidikan Indonesia \\ Jalan Dr. Setabudhi No. 229 Bandung 40154 \\ 2tatangherman@upi.edu \\ 3turmudi@upi.edu
}

Artikel diterima: 03-10-2018, direvisi: 27-01-2019, diterbitkan: 31-01-2019

\begin{abstract}
Abstrak
Memiliki kemampuan literasi matematis yang baik diharapkan dapat membantu siswa memecahkan masalah yang berkaitan dengan matematika. Fokus keterampilan literasi matematika pada siswa adalah kemampuan untuk menganalisis, membenarkan, dan mengkomunikasikan ide secara efektif, merumuskan, memecahkan dan menafsirkan masalah matematika dalam berbagai bentuk dan situasi. Tujuan dari penelitian ini adalah mengembangkan lembar kerja siswa berbasis masalah yang valid dan praktis untuk meningkatkan kemampuan literasi matematis siswa dalam materi sistem persamaan linear dua variabel. Jenis penelitian adalah penelitian pengembangan (Research and Development), yang terdiri dari tahap-tahap studi literatur, studi, observasi, wawancara, pengembangan lembar kerja siswa. Kesimpulan dalam penelitian ini adalah hasil ujicoba dalam skala kecil dan skala besar menunjukan angka 70,66\% dan 75,08\%, ini berarti LKS berbasis masalah untuk meningkatkan keterampilan literasi matematika dapat digunakan dan didistribusikan sebagai bahan pembelajaran dalam pembelajaran matematika untuk SMP.

Kata Kunci: Penelitian pengembangan, lembar kerja siswa, literasi matematis.
\end{abstract}

\section{Development Problem Based Student Worksheet with Heuristic Strategy to Improve Mathematics Literacy Skill}

\begin{abstract}
Having good mathematical literacy skills is expected to help students solve problems related to mathematics. The focus of mathematics literacy skills on students is the ability to analyze, justify, and communicate ideas effectively, formulate, solve and interpret mathematical problems in various forms and situations The purpose of this study was to determine the development process based problems student worksheet to improve mathematical literacy skill valid and practical problems in the system linear equations of two variables material. The type of research was the development of research (Research and Development), which consists of stages are literature, study, observation, interviews, development of student worksheets. After Revised, the student worksheets were evaluated by a field test in a small and large scale. The scale from both are $70,66 \%$ and $75,08 \%$ respectively. It is concluded that problem based student worksheet to improve mathematical literacy skill can be used and distributed as a learning material in mathematics learning for junior high school.

Keyword: Development reseacrh, Student worksheets, Mathematical literacy.
\end{abstract}




\section{Pendahuluan}

Tujuan kurikulum 2013 adalah untuk mempersiapkan orang Indonesia yang memiliki kemampuan untuk menjadi pribadi yang taat, produktif, kreatif, inovatif, dan afektif yang dapat berkontribusi terhadap bangsa dan dunia. Proses pembelajaran dalam kurikulum 2013 didasarkan pada pembelajaran berpusat pada siswa untuk menguasai kompetensi dasar dan inti sehingga siswa dapat memahami seluruh konsep. Oleh karena itu, guru dituntut untuk kreatif (Afriansyah, 2017) dan perlu memiliki kemampuan dalam membuat berbagai siswa untuk belajar mandiri. Matematika adalah salah satu mata kuliah wajib yang diajarkan di setiap jenjang pendidikan di Indonesia, mulai dari Sekolah Dasar (SD) hingga pendidikan tinggi, Sekolah Menengah Atas (SMA).

Tujuan mengajar matematika adalah untuk membekali siswa agar memiliki kemampuan berpikir logis, analitis, sistematis, kritis dan kreatif serta kemampuan mereka untuk bekerja sama. Melalui tujuan ini diharapkan siswa dapat mengembangkan kemampuan menggunakan matematika dalam memecahkan masalah yang berkaitan dengan kehidupan sehari-hari. Berdasarkan tujuan tersebut, matematika sangat penting bagi siswa untuk belajar.

Dalam belajar matematika, untuk mencapai tujuan pembelajaran yang diharapkan, harus menekankan prinsipmacam persoalan yang dapat menuntut

prinsip pembelajaran matematika. Dengan prinsip-prinsip dalam proses pembelajaran, siswa dapat mengembangkan ilmu pengetahuan, daya kreatif dan bertanggung jawab atas jalannya proses pembelajaran matematika. Sehingga siswa dapat memahami konsep matematika, dan dapat menerapkan konsep-konsep ini dalam masalah sehari-hari. Dengan demikian, pembelajaran diharapkan berhasil dengan baik.

Kegiatan belajar matematika dikatakan berhasil jika hasil belajar siswa mencapai hasil yang optimal. Untuk alasan ini, dukungan dari semua pihak diperlukan. Dan dukungan dari semua komponen pembelajaran. Satu komponen pembelajaran adalah bahan ajar yang digunakan oleh guru. Bahan ajar adalah seperangkat materi pembelajaran yang disusun secara sistematis, yang digunakan oleh guru dan siswa dalam proses pembelajaran. Contoh bahan ajar berupa buku, lembar kerja, dan modul yang dapat digunakan oleh siswa atau guru. Lembar kerja siswa adalah lembaran lembaran berisi tugas yang harus dikerjakan oleh siswa. LKS berisi panduan bagi siswa yang digunakan untuk melakukan kegiatan penyelidikan atau pemecahan masalah (Trianto, 2010).

LKS memuat sekumpulan kegiatan mendasar yang harus dilakukan oleh siswa untuk memaksimalkan pemahaman dalam upaya pembentukan kemampuan dasar sesuai indikator pencapaian hasil belajar yang harus ditempuh. LKS terdiri atas 
enam komponen, yaitu judul, petunjuk belajar (petunjuk siswa), kompetensi yang akan dicapai, informasi pendukung, tugastugas dan langkah langkah kerja, serta penilaian. Merancang sistematika dan struktur LKS (Nengsih \& Septia, 2017) perlu waktu yang tidak sebentar. Yang dimaksud dengan LKS dalam penelitian ini adalah lembaran kegiatan siswa yang dirancang menggunakan pendekatan berbasis masalah pada materi SPLDV yang memuat masalah, kegiatan belajar, informasi dan latihan bagi siswa.

LKS yang dikembangkan merupakan modifikasi LKS yang membantu siswa menemukan suatu konsep dengan LKS yang berfungsi sebagai petunjuk belajar. Adapun LKS ini diawali dengan menghadapkan siswa pada suatu permasalahan dalam kehidupan seharihari, kemudian kegiatan yang dapat membimbing siswa menemukan konsep agar siswa dapat menyelesaikan masalah, serta memberikan kesempatan siswa untuk menggunakan bahasanya sendiri dalam menyimpulkan hasil dari kegiatan yang dilakukan. Tujuan penelitian ini adalah untuk menghasilkan Lembar kerja siswa berbassi masalah pada materi sistem persamaan linear dua variabel. Melalui materi SPLDV ini pula, Rahayu \& Afriansyah (2015) membuat LKS berbasis pada level kesulitan soal, diharapkan pada penelitian ini LKS yang dibuat dapat lebih baik dari penelitian sebelumnya.

Dalam Permendikbud No 65 tahun 2013 tentang standar proses bahwa guru diwajibkan untuk menyusun RPP secara

\section{Mosharafa: Jumal Pendidikan Matematika}

Volume 8, Nomor 1, Januari 2019

Copyright @ 2019 Mosharafa: Jurnal Pendidikan Matematika lengkap dan sistematis agar pembelajaran berlangsung secara interaktif, inspiratif, menyenangkan, menantang, efesien, memotivasi siswa untuk berpartisipasi aktif, serta memberikan ruang yang cukup bagi prakarsa, kreativitas, dan kemandirian sesuai dengan bakat, minat dan perkembangan fisik serta psikologis siswa.

Beberapa teori belajar yang mendukung dalam pengembangan bahan ajar adalah Bruner (dalam Siregar E dan Nara H, 2010:33) mengusulkan teori free discovery learning bahwa proses belajar akan berjalan dengan baik dan kreatif jika guru memberikan kesempatan kepada siswa untuk menemukan suatu aturan (termasuk konsep, teori, defenisi dan sebagainya) melalu contoh-contoh yang menggambarkan (mewakili) aturan yang menjadi sumbernya. Selain itu teori konstruktivistik yang didasari oleh Glaserverd, Benntencourt dan Matthews (dalam Siregar E dan Nara H, 2010: 33) bahwa pengetahuan yang dimiliki seseorang merupakan hasil konstruksi (bentukan) orang itu sendiri. Sementara Piaget (dalam Trianto, 2014:29) mengemukakan bahwa perkembangan kognitif sebagai suatu proses dimana anak secara anak secara aktif membangun sistem makna dan pemahaman realitas melalui pengalaman-pengalaman dan interaksi-interaksi mereka. Implikasinya dalam pembelajaran saat guru memperkenalkan informasi yang melibatkan siswa menggunakan konsepkonsep, memberikan waktu yang cukup 
untuk menemukan ide-ide dengan menggunakan pola berpikir formal.

Kurikulum 2013 menekankan pada dimensi pedagogik modern dalam pembelajaran melalui pendekatan ilmiah (Scientific Approach). Pendekatan ilmiah dalam Kurikulum 2013 lebih dikenal dengan pendekatan saintifik. Pembelajaran dengan pendekatan saintifik tidak hanya memandang hasil belajar sebagai muara akhir, namun proses pembelajaran dipandang sangat penting. Oleh karena itu pembelajaran dengan pendekatan saintifik menekankan pada ketrampilan proses (Dirjen Dikmen, 2014:6).

Menurut Darmojo dan Kaligis (dalam Widjajanti, 2008: 2-3) bahwa LKS yang baik dalam pembelajaran hendaknya memiliki syarat kelayakan ditinjau dari tiga aspek yaitu didaktik, konstruksi dak teknik. Syarat didaktik artinya mengacu pada azas pembelajaran yang efektif antara lain memperhatikan adanya perbedaan individual, menekankan proses penemuan konsep, memiliki variasi stimulus dan mengembangkan komunikasi sosial, moral dan estetika anak. Selain itu syarat konstruksi yaitu syarat yang berhubungan dengan penggunaan bahasa, susunan kalimat, kosa kata, tingkat kesukaran dan kejelasan yang pada hakekatnya harus tepat guna dalam arti dapat dimengerti oleh pihak pemakai atau siswa. Dan syarat teknik yaitu syarat yang meliputi pengaturan tulisan, penyediaan gambar, kemasan/penampilan yang menarik.

\section{KAJIAN TEORI}

Salah satu sumber belajar yang dapat dikembangkan guru dalam RPP adalah bahan ajar berupa Lembar Kerja Siswa (LKS). Sumber belajar merupakan komponen minimal yang terdapat dalam RPP sehingga LKS merupakan satu diantara komponen minimal yang harus dikembangkan guru dalam RPP. LKS hendaknya dikembangkan oleh guru sesuai dengan tuntutan kurikulum, karakteristik siswa dan tuntutan pemecahan masalah belajar (Depdiknas, 2008:10). Ausubel (dalam Siregar E dan Nara H, 2010:33) mengatakan bahwa siswa akan belajar dengan baik jika isi pelajaran (instructional content) sebelumnya didefenisikan dan kemudian dipresentasikan dengan baik dan tepat kepada siswa (advance organizers).

Trianto (2008:222) menyatakan bahwa LKS adalah panduan siswa yang digunakan untuk melakukan kegiatan penyelidikan atau problem solving. Ahmadi (2011:77) juga mengungkap bahwa LKS dimaksudkan untuk mengaktifkan siswa, membantu siswa menemukan konsep, menjadi alternatif cara penyajian materi pelajaran yang menekankan keaktifan siswa serta dapat memotivasi. Dengan demikian, LKS bermanfaat sebagai salah satu alternatif bahan ajar yang dapat mengaktifkan siswa dalam pembelajaran untuk menemukan dan mengembangkan konsep sehingga dapat memfasilitasi kemampuan literasi matematis matematis siswa. 
Beberapa teori belajar yang memperhatikan adanya perbedaan mendukung dalam pengembangan bahan ajar adalah Bruner (dalam Siregar E dan Nara H, 2010:33) mengusulkan teori free discovery learning bahwa proses belajar akan berjalan dengan baik dan kreatif jika guru memberikan kesempatan kepada siswa untuk menemukan suatu aturan (termasuk konsep, teori, defenisi dan sebagainya) melalui contoh-contoh yang menggambarkan (mewakili) aturan yang menjadi sumbernya. Selain itu teori konstruktivistik yang didasari oleh Glaserverd, Benntencourt dan Matthews (dalam Siregar E dan Nara H, 2010: 33) bahwa pengetahuan yang dimiliki seseorang merupakan hasil konstruksi (bentukan) orang itu sendiri. Sementara Piaget (dalam Trianto, 2014:29) mengemukakan bahwa perkembangan kognitif sebagai suatu proses dimana anak secara anak secara aktif membangun sistem makna dan pemahaman realitas melalui pengalaman-pengalaman dan interaksi-interaksi mereka. Implikasinya dalam pembelajaran saat guru memperkenalkan informasi yang melibatkan siswa menggunakan konsepkonsep, memberikan waktu yang cukup untuk menemukan ide-ide dengan menggunakan pola berpikir formal.

Menurut Darmojo dan Kaligis (dalam Widjajanti, 2008: 2-3) bahwa LKS yang baik dalam pembelajaran hendaknya memiliki syarat kelayakan ditinjau dari tiga aspek yaitu didaktik, konstruksi dak teknik. Syarat didaktik artinya mengacu pada azas pembelajaran yang efektif antara lain individual, menekankan proses penemuan konsep, memiliki variasi stimulus dan mengembangkan komunikasi sosial, moral dan estetika anak. Selain itu syarat konstruksi yaitu syarat yang berhubungan dengan penggunaan bahasa, susunan kalimat, kosa kata, tingkat kesukaran dan kejelasan yang pada hakekatnya harus tepat guna dalam arti dapat dimengerti oleh pihak pemakai atau siswa. Dan syarat teknik yaitu syarat yang meliputi pengaturan tulisan, penyediaan gambar, kemasan/penampilan yang menarik

Literasi matematis adalah kemampuan individu (individual's capacity) untuk mengenal dan memahami peran yang dimainkan matematika dalam kehidupan nyata, untuk mampu memberikan penilaian dan pertimbangan secara tepat, memanfaatkan matematika yang dapat memenuhi kebutuhan seseorang menjadi anggota masyarakat yang konstruktif, peduli, dan mau berpikir (OECD, dalam Kusumah 2011). Dalam pengertian ini, literasi matematis digunakan untuk memberi penekanan pada pengetahuan matematis, yang digunakan dalam kehidupan sehari-hari. Menurut de Lange (Kusumah 2011), literasi matematis tidak sebatas mencakup melaksanakan sejumlah cara atau prosedur, dan memiliki pengetahuan dasar matematis. Literasi matematis juga mencakup pengetahuan, metode, dan proses matematis, yang digunakan dan dimanfaatkan dalam berbagai konteks dengan cara memberi inspirasi dan membuka wawasan

\section{Mosharafa: Jurnal Pendidikan Matematika}


pemikiran. Sejalan dengan pendapat yang dikemukakan oleh Niis (dalam Kusumah, 2011) yang menyatakan bahwa literasi matematis mencakup delapan kompetensi yang harus dimiliki, yaitu: 1) penalaran dan berpikir matematis, 2) argumentasi matematis, 3) komunikasi matematis, 4) pemodelan, 5) pengajuan dan pemecahan masalah, 6) representasi, 7) symbol, 8) media dan teknologi. Secara spesifik, penilaian literasi matematis siswa yang diakukan PISA terdiri atas 6 tingkatan atau level. level 6 sebagai tingkat pencapaian yang paling tinggi dan level 1 yang paling rendah. Setiap level tersebut menunjukkan tingkat kompetensi matematika yang dicapai siswa.

Penelitian ini menggunakan metode penelitian dan pengembangan (R\&D). Menurut Sugiyono (2014:407) metode penelitian dan pengembangan adalah penelitian yang digunakan untuk menghasilkan produk tertentu dan menguji keefektifitasan produk tersebut. Model pengembangan yang digunakan diadaptasi dari model pengembangan Borg \& Gall (1983:775) yang dimodifikasi menjadi lima langkah utama yaitu: (1) Melakukan studi pendahuluan untuk mengumpulkan informasi; mengembangkan produk awal; (3) validasi ahli dan revisi; (4) tahap uji coba lapangan dan revisi produk akhir ; (5) produk akhir berupa LKS berbasis masalah.

Subjek penelitian terdiri dari : (1) subjek pra uji coba untuk mengetahui aspek keterbacaan, kemenarikan dan kepraktisan LKS yang terdiri dari 6 orang siswa kelas IX 42
(Sembilan) SMPN Kota Tasikmalaya; dan (2) subjek uji coba lapangan untuk mengetahui kelayakan dan efektifitas LKS berbasis masalah yang terdiri dari 36 orang siswa kelas IX (sepuluh) SMPN Kota Tasikmalaya.

Data yang diperoleh bersifat kualitatif dan kuantitatif. Data kualitatif diperoleh dari saran/masukan validator, hasil observasi, catatan lapangan dan wawancara. Sedangkan data kuantitatif diperoleh dari penilaian validator berupa skor terhadap instrument penelitian, angket respon siswa dan nilai hasil tes kemampuan pemecahan masalah matematis. Prosedur penelitian yang dilakukan dalam penelitian ini dapat dilihat pada Bagan 1 berikut:

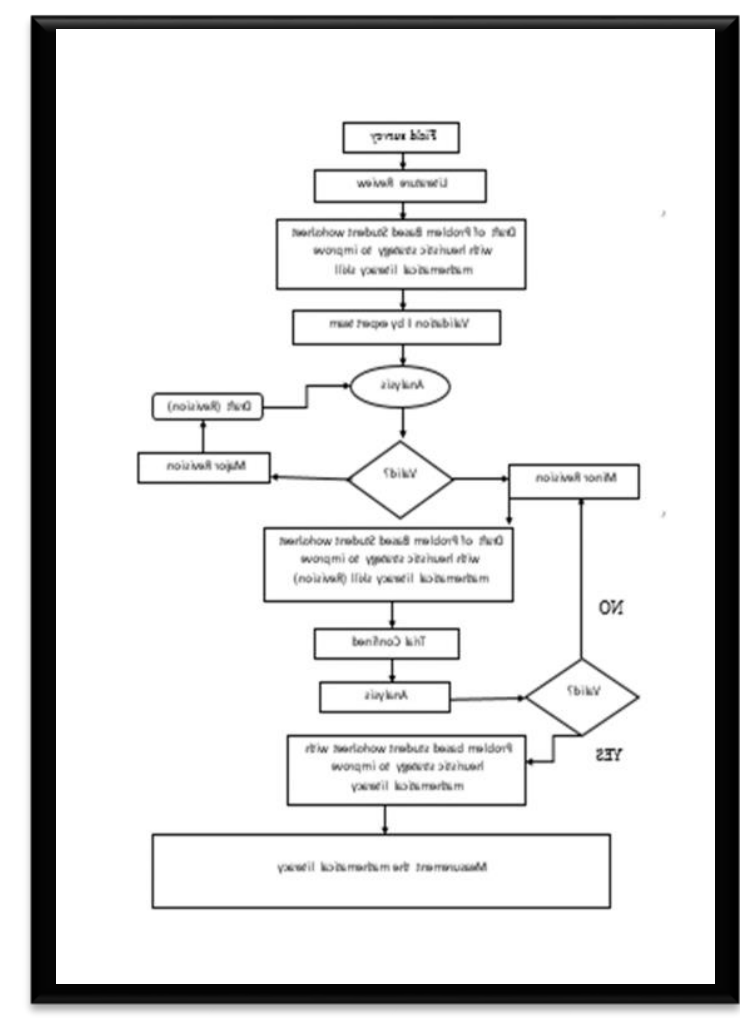

Bagan 1. Prosedur Penelitian. 


\section{Pembahasan}

Pada penelitian ini, kegiatan yang dilakukan dalam pengembangan LKS meliputi studi pendahuluan, pengembangan produk awal, validasi dan revisi, uji coba dan produk akhir berupa LKS berbasis masalah.

\section{A. Studi Pendahuluan}

Pada tahap studi pendahuluan kegiatan yang dilakukan adalah : (1) analisis kebutuhan untuk mengetahui masalah yang dihadapi dalam pembelajaran khususnya terkait penerapan Kurikulum 2013 dan solusi yang diberikan terkait penelitian; (2) analisis terhadap bahan ajar khususnya kesenjangan LKS antara tuntutan Kurikulum 2013 dan keadaan saat penelitian berlangsung; (3) analisis siswa untuk mengetahui karakteristik siswa sebagai acuan dalam menyusun materi pembelajaran; (4) analisis kajian pustaka yang mendukung pengembangan bahan ajar LKS; dan (5) menentukan materi/kompetensi inti (KI)/kompetensi dasar (KD).

Pada tahap analisis kebutuhan, dilakukan kajian terhadap Kurikulum 2013 terkait tujuan pembelajaran dan proses pembelajaran berbasis masalah. Hasil analisis menunjukkan bahwa literasi matematis merupakan bagian dari kurikulum matematika yang sangat penting bahkan menjadi sasaran utama dalam pembelajaran matematika. Selanjutnya dilakukan analisis bahan ajar yaitu LKS yang digunakan guru dalam pembelajaran. LKS yang di analisis belum memenuhi proses pembelajaran dengan pendekatan saintifik terutama proses menanya, mencoba/mengumpulkan informasi dan mengkomunikasi. Sejatinya RPP yang telah dibuat oleh guru, menyertakan LKS sebagai lampiran untuk mencapai tujuan pembelajaran yang telah dirancang. Namun karena padatnya aktivitas guru, sehingga guru belum menyertakan LKS dalam RPP yang telah dibuat. Fungsi guru sebagai fasilitator belum sepenuhnya terlaksana. Sebagai gantinya guru memilih bahan ajar dari penerbit tertentu yang tersedia di pasaran. Akibatnya terjadi ketidaksesuaian anatara skenario dan fakta pembelajaran.

Dari hasil analisis peneliti terhadap beberapa LKS menunjukkan bahwa dalam penyajian LKS, guru masih di dominasi oleh proses mengasosiasi/menalar. Dalam pembelajaran matematika guru belum merancang LKS dengan proses pendekatan saintifik khususnya pada proses menanya.

Dari hasil analisis LKS, peneliti menemukan bahwa dalam tahapan problem solving guru cenderung menyajikan penyelesaian masalah pada tahapan merencanakan problem solving dan menyelesaikan masalah. Akibatnya siswa tidak terbiasa untuk melakukan problem solving melalui tahapan problem solving khususnya memeriksa kembali kebenaran hasil yang mereka peroleh. Hal ini disebabkan guru belum menerapkan tahapan problem solving dalam pembelajaran sehingga siswa lebih tertarik kepada hasil bukan proses. 
Pada tahap analisis siswa, dilakukan kajian terhadap karakterisitik siswa SMP Negeri kota Tasikmalaya meliputi kemampuan siswa, latar belakang pengetahuan siswa dan tingkat perkembangan kognitif siswa. Hasil analisis siswa diketahui bahwa kemampuan siswa dalam pembelajaran matematika masih kurang. Hal ini dilihat dari hasil tes kemampuan pemecahan masalah hanya 40,74\% siswa tuntas (kriteria ketuntasan >66). Ditinjau dari latar belakang pengetahuan siswa bahwa materi persamaan kuadrat sudah dikenalkan kepada siswa ketika mereka di SMP. Tingkat perkembangan kognitif untuk usia siswa SMA sudah memahami masalah dalam bentuk verbal dan mampu menyelesaikan masalah dengan cara yang lebih baik dan kompleks (Slavin dalam Trianto, 2013:197).

Hasil analisis kajian pustaka dari beberapa penelitian sebelumnya menunjukkan bahwa pengembangan bahan ajar mampu meningkatkan kemampuan problem solving siswa. Pada tahap penentuan Kompetensi Inti dan Kompetensi Dasar yang akan diambil dalam penelitian, maka dipilih materi persamaan kuadrat dengan empat sub pokok bahasan yaitu menemukan konsep persamaan kuadrat, menentukan akarakar persamaan kuadrat, menentukan jumlah dan hasil kali akar, dan persamaan kuadrat dengan 1 dan 2.

\section{B. Tahap Pengembangan Produk Awal}

Pada tahap ini, kegiatan yang dilakukan adalah merancang dan mengembangkan produk awal. Dalam merancang produk awal dilakukan analisis konsep materi sistem persamaan linear dua variabel, menentukan prototipe yang disesuaikan dengan syarat kelayakan LKS (didaktik, konstruksi dan teknik) serta memuat aspek-aspek pendekatan berbasis masalah dan melatih siswa menyelesaikan masalah melalui tahapan proses literasi matematis.

Rancangan produk awal LKS terdiri dari halaman identitas LKS (Judul LKS, kolom identitas siswa dan sekolah, identitas mata pelajaran dan kompetensi inti/kompetensi dasar/indikator), halaman aktivitas siswa menyajikan materi dengan masalah kontekstual yang mengantarkan siswa pada penemuan konsep materi.

\section{Tahap Validasi Ahli dan Revisi}

Pada tahap ini kegiatan yang dilakukan antara lain:

1. Pra uji coba untuk mengetahui tingkat keterbacaan, kemenarikan dan kepraktisan LKS. Revisi keterbacaan dilakukan terhadap beberapa istilah atau kalimat yang sulit dipahami siswa. Untuk kemenarikan dapat dilihat dari respon siswa pada angket bahwa minat siswa terhadap LKS berbasis masalah sebesar 75\% (baik) dan tampilan LKS sebesar 79,17\% (Baik). Dengan demikian dapat disimpulkan bahwa LKS memiliki kemenarikan bagi siswa. Untuk kepraktisan LKS dilihat dari angket respon siswa sebesar 70,83\% (baik) dan 100\% 
kategori respon siswa baik sehingga disimpulkan respon siswa terhadap LKS positif.

\section{Validasi ahli}

Validasi ahli melibatkan 2 orang dosen matematika dan 2 orang guru matematika. Validasi dilakukan terhadap produk penelitian yaitu LKS dengan pendekatan saintifik. Tujuan validasi LKS untuk melihat tingkat kelayakan LKS ditinjau dari syarat didaktik, teknik dan konstruksi. Hasil validasi disajikan dalam Tabel 1 berikut:

Tabel 1.

Rekapitulasi Penilaian Kelayakan LKS

\begin{tabular}{lcc|}
\hline $\begin{array}{l}\text { Kriteria Kelayakan } \\
\text { LKS }\end{array}$ & $\begin{array}{c}\text { Perolehan } \\
\text { Skor }(\%)\end{array}$ & Kategori \\
\hline Syarat Didaktik & $92,50 \%$ & Sangat Baik \\
\hline Syarat Konstruksi & $94,09 \%$ & Sangat Baik \\
\hline Syarat Teknik & $95,00 \%$ & Sangat Baik \\
\hline Rata-rata & $93,86 \%$ & Sangat Baik \\
\hline
\end{tabular}

Selain itu validasi dilakukan terhadap RPP dan soal tes kemampuan literasi matematis. Dari hasil validasi RPP diperoleh rata-rata tingkat kevalidan RPP sebesar 91,74\% kategori sangat baik. Untuk tes kemampuan literasi matematis dilakukan validasi isi. dari 5 soal yang disajikan validator memberikan penilaian valid terhadap kelima butir soal. Dengan demikian tes kemampuan literasi matematis tergolong valid. Sedangkan untuk mengetahui reliabilitas tes digunakan rumus Alpha diperoleh nilai sebesar 0,72 kategori tinggi. Sehingga disimpulkan bahwa tes kemampuan literasi matematis yang dibuat tergolong valid dan reliabel.

3. Revisi produk awal
Revisi produk awal berdasarkan komentar dan saran dari validator yaitu 2 orang dosen matematika dan 2 orang guru matematika. Dari saran/masukan validator, peneliti melakukan perbaikan pada beberapa bagian LKS yaitu :

a) Menambahkan contoh dan non contoh dalam LKS. Sebelumnya pada paparan materi tidak diawali dengan pemberian contoh dan non contoh.

b) Semula siswa diminta membuat denah lengkap dengan ukurannya direvisi menjadi melengkapi gambar denah kebun sehingga siswa hanya melengkapi gambar.

c) Menambahkan kotak Notice berisi pengantar secara umum tentang materi yang akan dibahas.

d) Mengganti beberapa istilah yang lebih sesuai dengan tata Bahasa

e) Mengganti beberapa pertanyaan terbuka menjadi melengkapi isian seperti pada tahapan menanya dan kolom pada basic concept.

\section{Tahap Uji Coba Lapangan}

Uji coba lapangan dilakukan terhadap 36 orang siswa kelas IX (sembilan) SMP Negeri Tasikmalaya yang terdiri dari 12 orang siswa dengan kemampuan rendah, 12 orang siswa dengan kemampuan sedang dan 12 orang siswa dengan kemampuan tinggi. Dalam pembelajaran dengan menggunakan LKS berbasis masalah diamati oleh 2 orang guru untuk mengamati kemampuan guru mengelola pembelajaran dan 7 orang pengamat yang bertugas mengamati aktivitas siswa

\section{Mosharafa: Jurnal Pendidikan Matematika}


selama pembelajaran. Hasil observasi aktivitas siswa dan kemampuan guru mengelola pembelajaran secara keseluruhan tergolong ideal.

Setelah pembelajaran siswa diberikan tes kemampuan literasi dan angket respon siswa. Berdasarkan hasil tes kemampuan literasi matematis yang diberikan diperoleh ketuntasan sebesar 91,67\%. Hal ini menunjukkan bahwa LKS berbasis masalah tergolong efektif dalam pembelajaran materi sistem persamaan linear dua variabel.

\section{Penutup}

Berdasarkan hasil penelitian dan pengembangan LKS berbasis masalah dapat disimpulkan bahwa (1) prototipe LKS menyajikan materi melalui penerapan proses pembelajaran dengan pendekatan berbasis masalah yaitu mengamati, menanya, mencoba/mengumpulkan informasi, menalar/mengasosiasi dan mengkomunikasikan (2) Ditinjau dari syarat kelayakan LKS yaitu didaktik, konstruksi dan teknik diperoleh rata-rata skor kelayakan sebesar 93,86\% dengan kategori sangat baik; (3) LKS tergolong efektif karena telah memenuhi keempat komponen efektif dalam penelitian yaitu tes kemampuan literasi matematis sebesar 91,67\% siswa tuntas, aktivitas siswa sebesar 3,76 dengan kategori sangat baik, rata-rata kemampuan guru mengelola pembelajaran sebesar 3,83 dengan kategori sangat baik dan rata-rata persentase respon siswa sebesar 88,89\% dengan kategori sangat baik.

Saran dalam penelitian ini adalah: (1) LKS berbasis masalah tergolong efektif untuk memfasilitasi kemampuan literasi matematis siswa sehingga dapat digunakan dalam pembelajaran khusunya materi SPLDV; (2) guru hendaknya selalu berinovasi dalam mengembangkan bahan ajar yang sesuai dengan tuntutan kurikulum dan karakteristik siswa; (3) penyajian materi dalam LKS berbasis masalah dapat dikembangkan sesuai dengan pemilihan strategi, metode, pendekatan dan sumber belajar yang digunakan. Keterbatasan dalam penelitian ini adalah subjek penelitian hanya dilakukan di satu sekolah, yaitu salah satu SMPN di kota Tasikmalaya. Terbuka peluang bagi peneliti untuk meneliti pada sekolah dengam kategori tinggi, sedang, dan rendah serta dapat pula meneliti pada level SD dan SMA.

\section{DAftar Pustaka}

Afriansyah, E. A. (2017). Problem Posing merupakan Kemampuan Matematis. Mosharafa: Jurnal Pendidikan Matematika, 6(1), 163-180.

Ahmadi I.K, Amri S. (2011). Paikem Gembrot (Mengembangkan Pembelajaran Aktif, Inovatif, Kreatif, Efektif, Menyenangkan, Gembira dan Berbobot). Jakarta: Prestasi Pustaka Publisher.

Borg and Gall. (1983). Education Research. New York: Longman. 
Departemen Pendidikan Nasional. (2008).

Direktorat Pendidikan Sekolah

Menegah atas. Panduan

Pengembangan Bahan Ajar. Jakarta:

Depdiknas

Direktorat Jendral Pendidikan Menengah.

(2014). Pembelajaran Matematika

Melalui Pendekatan Saintifik. Jakarta:

Kemdikbud.

Hobri H. (2009). Metode Penelitian Pengembangan (Developmental Research) Aplikasi pada Penelitian Pendidikan Matematika. Jember: Word Editor

Ibrahim. (2011). Pengembangan Bahan Ajar Matematika sekolah berbasis masalah Terbuka Untuk Memfasilitasi Pencapaian Kemampuan Berpikir Kritis dan Kreatif Matematis siswa. Di dalam Seminar Nasional Matematika dan Pendidikan Matematika; Yogyakarta: FMIPA UNY. Halaman 121-132.

IEA (Evaluation of Education Achievement). (2012). TIMSS (Trends in International Mathematics and Science Study) 2011 International Results in Mathematics. Amsterdam: Publisher TIMSS \& PIRLS International Study Center.

Kurnik Z. (2008). The Scientific Approach to Teaching Math. Metodika 17 (2/2008) Profesional Paper: 421-432. Melati, A. (2014). Pengembangan Modul Praktikum Astrofisika Seri Alat Solarscope Berbasis Integrasi Interkoneksi. Prosiding Pertemuan
IImiah XXVIII Jateng \& DIY, Yogyakarta, 26 April 2014. ISSN: 0853-0823.

National Council of Teachers of Mathematics. (2000). Principles and Standards for School Mathematics. Reston: NCTM.

Nengsih, S. \& Septia, \&. (2017). Pengembangan Lembar Kegiatan Siswa Berbasis Penemuan Terbimbing pada Materi Peluang untuk Siswa Kelas XI IPA SMA Adabiah 2 Padang. Mosharafa: Jurnal Pendidikan Matematika, 6(1), 163-180.

Organisation for Economic Co- Operation and Development. (2013). (PISA) Programmefor International Student Assesment 2012 Assesment and Analytical Framework: Mathematics, Reading, Science, Problem solving and Financial Literacy. England: OECD Publishing.

Peraturan Pemerintah Pendidikan dan Kebudayaan. (2013). Implementasi Kurikulum Pedoman Umum Pembelajaran. Jakarta: Kemdikbud.

Peraturan Pemerintah Pendidikan dan Kebudayaan. (2014). Kurikulum 2013 Sekolah Menengah atas (SMA)/Madrasah aliyah (MA). Jakarta. Kemdikbud.

Perbowo. (2012). Pengembangan Desain Didaktis Bahan Ajar Pemecahan Masalah Matematis Sistem Persamaan Linier Dua Variabel (SPLDV) pada Sekolah Menengah Pertama. Tesis. Universitas Pendidikan Indonesia. Bandung. 
Polya G. (1973). How to Solve It. New Jersey: Princeton University Press.

Rahayu, D. V. \& Afriansyah, E. A. (2015). Meningkatkan Kemampuan Pemecahan Masalah Matematik Siswa melalui Model Pembelajaran Pelangi Matematika. Mosharafa: Jurnal Pendidikan Matematika, 4(1), 29-37.

Rohati. (2011). Pengembangan Bahan Ajar Materi Bangun Ruang dengan Menggunakan Strategi REACT di SMP. Jurnal Edumatica Volume 01 nomor 02. Jambi.

Siregar E. dan Nara H. (2010). Teori Belajar dan Pembelajaran. Bogor: Ghalia Indonesia.

Sugiyono. (2014). Metode Penelitian Pendidikan Pendekatan Kuantitatif, Kualitatif dan $R$ \& D. Bandung: Alfabeta.

Syaiful. (2012). Peningkatan Kemampuan Pemecahan Masalah Matematis Melalui Pendekatan Pendidikan Matematika Realistik. Jambi: Jurnal Edumatica Volume 02 nomor 01

Trianto. (2014). Mendesain Model Pembelajaran Inovatif-Progresif.

Konsep (Landasan dan Implementasinya pada Kurikulum tingkat Satuan) Pendidikan. Kencana Prenada Media Grup. Jakarta.

Varelas M and Ford M. (2009) The Scientific Methode and Scientific inquiry: Tensions in teaching and Learning. USA: Willey InterScience.

Widjajanti E. (2008). Kualitas Lembar Kerja Siswa. Makalah Seminar Pelatihan Penyusunan LKS untuk guru SMK/MAK pada kegiatan PPM. Universitas Yogyakarta.

\section{Riwayat Hidup Penulis \\ Mega Nur Prabawati, M.Pd.}

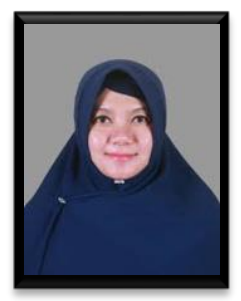

Lahir di Tasikmalaya, 24 Januari 1988. Dosen Pendidikan Matematika di Universitas Siliwangi. Studi S1 Pendidikan Matematika Universitas Siliwangi Tasikmalaya, lulus tahun 2009; S2 Pendidikan Matematika Universitas Pendidikan Indonesia Bandung, lulus tahun 2011; dan sedang melanjutkan S3 Pendidikan Matematika di Universitas Pendidikan Indonesia Bandung sampai sekarang.

\section{Prof. Tatang Herman, M.Ed.}

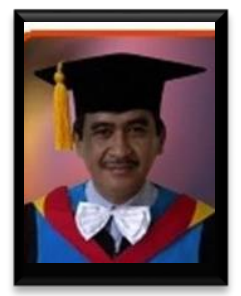

\section{Dosen} Pendidikan Matematika di Universitas Pendidikan Indonesia.

\section{Prof. Turmudi, M.Sc., M.Ed., Ph.D.}

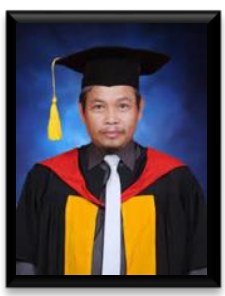

Dosen Pendidikan Matematika di Universitas Pendidikan Indonesia. 